\title{
DIRECTIONS FOR THE DEVELOPMENT OF TRANSPORT MACHINES FOR OPEN-PIT MINING
}

Vladimir Yurievich Koptev

Saint Petersburg Mining

University, Mechanical

Engineering Department,

Saint Petersburg, Russia
Alexandra Vladimirovna Kopteva

Saint Petersburg Mining

University, Energy Department,

Saint Petersburg, Russia

\section{Tatiana Sergeevna Ivanova}

Saint Petersburg Mining

University, Energy Department,

Saint Petersburg, Russia

Key words: open-pit mining, development trends, systematization, technical solutions, transportation system, mining enterprises

Cite article:

Nazam, A., Muhammad, A. J., Syed, A. H., \& Abdur, R. [2021]. Directions for the development of transport machines for open-pit mining. Journal of Applied Engineering Science, 19(1), 137 - 141. DOI:10.5937/jaes0-28708

Online aceess of full paper is available at: www.engineeringscience.rs/browse-issues 
doi:10.5937/jaes0-28708

\title{
DIRECTIONS FOR THE DEVELOPMENT OF TRANSPORT MACHINES FOR OPEN-PIT MINING
}

\author{
Vladimir Yurievich Koptev ${ }^{1}$, Alexandra Vladimirovna Kopteva ${ }^{2 *}$, Tatiana Sergeevna Ivanova ${ }^{2}$ \\ ${ }^{1}$ Saint Petersburg Mining University, Mechanical Engineering Department, Saint Petersburg, Russia \\ ${ }^{2}$ Saint Petersburg Mining University, Energy Department, Saint Petersburg, Russia
}

The paper is devoted to the identification (in the form of an intermediate obtained result) of the main trends in the development of transport machines, their systematization, taking into account the current state of art, identification and assessment of the most significant trends in view of innovative prospects. The discussed technical solutions contribute to a significant modernization of transport systems of mining enterprises.

Key words: open-pit mining, development trends, systematization, technical solutions, transportation system, mining enterprises

\section{INTRODUCTION}

The current state of art with respect to transport systems for open-pit mining makes it possible to successfully using them in many mineral deposits. This is true for the developed processing routes, various mining and geological conditions, geographical and climatic zones, mining stages and concepts, etc. [1-5].

However, current trends in the development of mining and the need in reduced material and financial costs, energy consumption and improved competitiveness require continuous improvement of economic, operating, technological and other characteristics of transport machines [6]. Practical experience [7-9] proves that it is impossible to create a transport system that could ensure efficient development of the field throughout the entire open pit lifetime, and it is necessary to separate the strategies for the formation and development of mining transport systems both for the enterprises, being start-ups in green fields, and for already operational mining enterprises. With an increase in the depth of an open pit, it is expedient to use several types and standard sizes of transport machines, taking into account their advantages and disadvantages considering the depth of the open pit or combined use thereof (in the form of combined systems). Due to the specifics of particular enterprises, not all of the proposed technical solutions can be recommended for a widespread application in practice. For example, the dump truck park formation algorithm (figure 1) for a mining enterprise is complex and involves a lot of parameters [10]. In connection therewith, the study deals with the most viable directions for the development of transport machines, deemed to be sustained development trends based on actually applied solutions for constructional, structural and functional enhancement, which contribute to a significant modernization of transport systems of mining enterprises; the study does not consider local solutions used in a particular mining technique or virtual ones that require using a different principle of operation and new physical and technical effects [11].

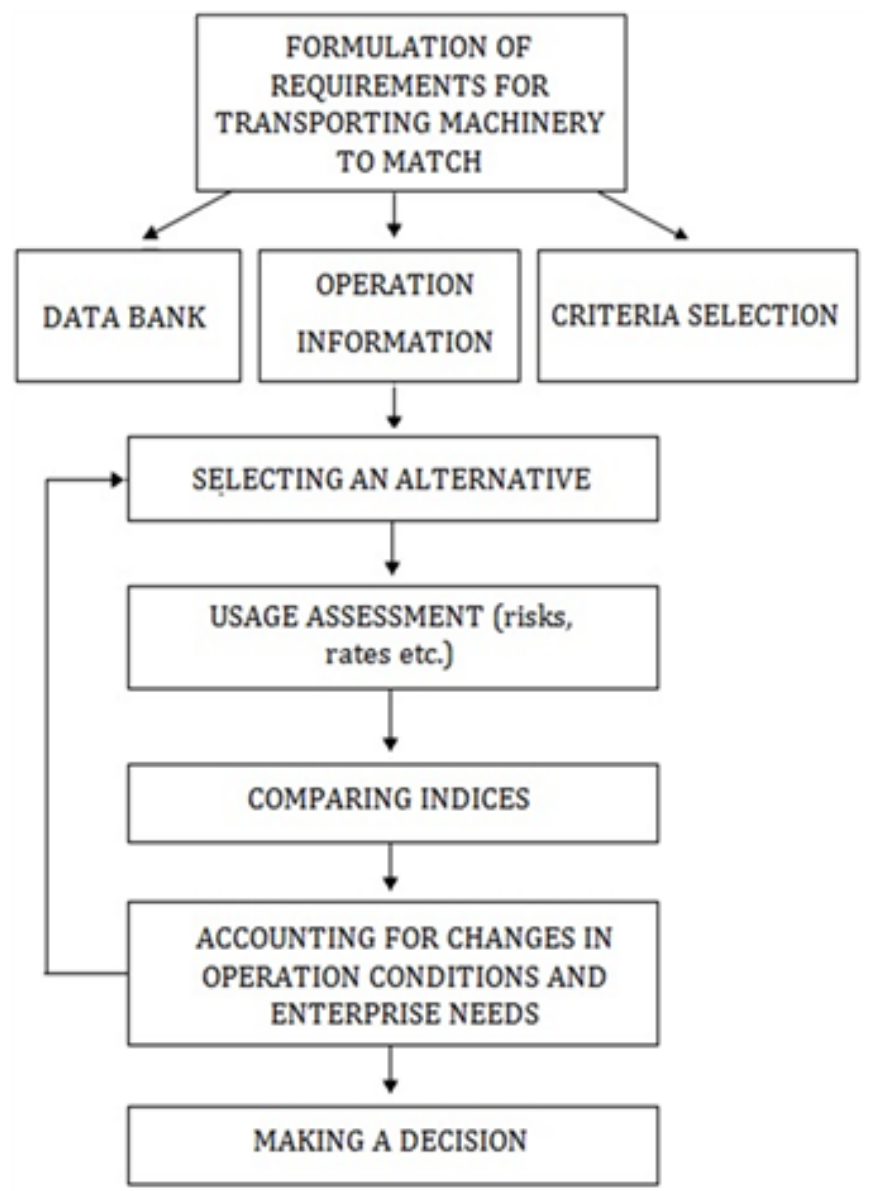

Figure 1: Algorithm of the dump truck park's formation

\section{METHODS}

The systematization of directions for the enhancement of transport equipment was conducted on the basis of fundamental criteria of the design and the state of art [12-13], considering current logistics requirements for transport [14].

When selecting development criteria based on the principle of progressive development for the next generations 
of machines, based on setting priorities when developing solutions to improve one but not to degrade other criteria, the potential improvement of constructional, structural and operating parameters of transport machines was accounted for to a sufficiently great extent and provided that the rest will have virtually stable effect. In view of the above, it is possible to reduce the number of other criteria in question, which simplifies presenting the research results [10].

We suggest the following criteria: functional - productivity, quality of the transportation and automation process [15-18] and technological criteria that include maintenance and repair [19, 20].

Functional criteria of development provide a quantitative characteristic of the main parameters for the performance of a machine, i.e., these criteria are determined on the basis of an analysis of a description of performance improvement when applying a technical solution. Since the functionality of a transport machine can be characterized by a variety of parameters, it is hardly possible to provide a limiting list of functional criteria [11]. In connection therewith, we have taken into consideration only the most important criteria for performing transport operations or optimization thereof during open-pit mining.
Direct economic criteria were not considered due to ambiguity of the determination for particular enterprises, the values, not fully confirmed by the developers, sometimes highly questionable and, consequently, their direct interest in selling their developments.

From the logistics requirements in the systematization of directions for the development, the key attention was focused on the possibility to improve controllability of transport operations [21-23].

It is worth noting that the generalization of technical solutions in the study and their systematization according to the criteria of the design and the state of art, considering the logistics requirements, coincide to a great extent for the main types of transport. During the selection, the key attention was focused on such actual solutions, which have outstanding significance, meet the requirements for the substantial improvement of technical characteristics (i.e., not inventive level) and are capable of providing great technological benefits when applied.

Based on the results of the analysis of automobile, railway and conveyor mining transport development directions, the selected applied solutions, being the most significant and promising for assessing their development for short-term prospects by types of mining transport, are summarized in the tables: for automobile (Table 1), railway (Table 2) and conveyor (Table 3) transport.

Table 1: Development directions and technical solutions in truck transport

\begin{tabular}{|c|c|c|c|}
\hline Directions & Solutions & Advantages & Disadvantages \\
\hline \multirow{2}{*}{$\begin{array}{l}\text { Increase in (or operational } \\
\text { control over) productivity }\end{array}$} & $\begin{array}{l}\text { Increased carrying capaci- } \\
\text { ty and unit capacity }\end{array}$ & $\begin{array}{l}\text { Reduced costs for trans- } \\
\text { portation by up to } 25 \%\end{array}$ & $\begin{array}{l}\text { Increased costs for pur- } \\
\text { chasing machines and } \\
\text { creating the required infra- } \\
\text { structure (roads, mainte- } \\
\text { nance and repair, loading } \\
\text { and unloading devices) }\end{array}$ \\
\hline & $\begin{array}{l}\text { The use of several trans- } \\
\text { port units, optionally, com- } \\
\text { bined into a road train }\end{array}$ & $\begin{array}{l}\text { Increased traction and } \\
\text { braking forces on slopes, } \\
\text { in a road train } \\
\text { Autonomous work at faces } \\
\text { and during unloading }\end{array}$ & $\begin{array}{l}\text { No domestic develop- } \\
\text { ments. } \\
\text { High level of dispatching is } \\
\text { required }\end{array}$ \\
\hline $\begin{array}{l}\text { Improving the quality of } \\
\text { transport operations due to } \\
\text { automation with the transi- } \\
\text { tion to full robotization }\end{array}$ & $\begin{array}{l}\text { Means of automobile au- } \\
\text { tomation systems with the } \\
\text { transition to full robotiza- } \\
\text { tion and navigation }\end{array}$ & $\begin{array}{l}\text { Remote and operational } \\
\text { control, accounting and di- } \\
\text { agnostics of operating and } \\
\text { technical parameters } \\
\text { Dispatching, including } \\
\text { remote }\end{array}$ & $\begin{array}{l}\text { Increased expenses up to } \\
15 \% \text { of the cost } \\
\text { There is a probability } \\
\text { of failure (including of } \\
\text { psychological nature) or } \\
\text { malicious interference }\end{array}$ \\
\hline \multirow{2}{*}{$\begin{array}{l}\text { Improving the use of tech- } \\
\text { nology when performing } \\
\text { technical maintenance }\end{array}$} & $\begin{array}{c}\text { Quick-detachable wheels } \\
\text { with tires }\end{array}$ & $\begin{array}{l}\text { Reduced labor costs and } \\
\text { idle time }\end{array}$ & No domestic techniques \\
\hline & $\begin{array}{c}\text { The use of an electric } \\
\text { traction drive of alternating } \\
\text { current }\end{array}$ & $\begin{array}{l}\text { Reduced maintenance } \\
\text { costs }\end{array}$ & Under development \\
\hline
\end{tabular}


Table 2: Development directions and technical solutions in railway transport

\begin{tabular}{|c|c|c|c|}
\hline Directions & Solutions & Advantages & Disadvantages \\
\hline \multirow{2}{*}{$\begin{array}{l}\text { Improving the use of tech- } \\
\text { nology when performing } \\
\text { technical maintenance }\end{array}$} & $\begin{array}{l}\text { Combined power plants } \\
\text { with hydrogen fuel cells }\end{array}$ & $\begin{array}{c}\text { Dispensing with the } \\
\text { contact line and diesel } \\
\text { engines, simplified main- } \\
\text { tenance }\end{array}$ & $\begin{array}{l}\text { High cost even under } \\
\text { development }\end{array}$ \\
\hline & $\begin{array}{l}\text { Cassette-type bearings for } \\
\text { wheel pairs }\end{array}$ & $\begin{array}{c}\text { Extended lifetime up to } 16 \\
\text { years } \\
\text { Thrice less frequent ser- } \\
\text { vicing }\end{array}$ & $\begin{array}{c}\text { Thrice higher in price } \\
\text { and the absence of serial } \\
\text { production }\end{array}$ \\
\hline $\begin{array}{l}\text { Improving the quality of } \\
\text { transport operations due to } \\
\text { automation with the transi- } \\
\text { tion to full robotization }\end{array}$ & $\begin{array}{l}\text { The use of means of auto- } \\
\text { mation systems of rolling } \\
\text { stock, railway lines and } \\
\text { means of communication } \\
\text { with the transition to full } \\
\text { robotization and navigation }\end{array}$ & $\begin{array}{c}\text { - Remote and operational } \\
\text { control and accounting of } \\
\text { operating and technical } \\
\text { parameters } \\
\text { Dispatching, including } \\
\text { remote }\end{array}$ & $\begin{array}{l}\text { Increased expenses up to } \\
20 \% \text { of the cost }\end{array}$ \\
\hline $\begin{array}{l}\text { Increase in (or operational } \\
\text { control over) productivity }\end{array}$ & $\begin{array}{l}\text { Multiple-unit type wagons } \\
\text { with increased volume of } \\
\text { transported cargo }\end{array}$ & $\begin{array}{l}\text { Increase in the volume } \\
\text { of transported cargo up } \\
\text { to } 40 \% \text { while maintaining } \\
\text { the standard train length } \\
\text { Reducing the fleet of cars }\end{array}$ & Under development \\
\hline
\end{tabular}

\section{RESULTS AND DISCUSSION}

The technical solutions selected and presented in the tables are fully disclosed in the Internet information systems and, to avoid advertising, are given in the tables in the form of their proved advantages, disadvantages and assessment of their implementation. More detailed descriptions thereof can be found on information resources by referring to the names (given in italics in the tables).
The return on investment (ROI, simple rate of return) [24], determined by the ratio of annual profit to investments involved in the project would allow one to determine and assess the project profitability. However, the difficulties of determining profits that have not been received yet and an unknown amount of investments for an abstract open pit will compromise the reliability of the resulting assessment of solutions. Actually, the rate of return is determined for the specific conditions of the de-

Table 3: Development directions and technical solutions in belt conveyor transport

\begin{tabular}{|c|c|c|c|}
\hline Directions & Solutions & Advantages & Disadvantages \\
\hline $\begin{array}{l}\text { Improving the quality of } \\
\text { transport operations due to } \\
\text { automation with the transi- } \\
\text { tion to full robotization }\end{array}$ & $\begin{array}{l}\text { The use of means of auto- } \\
\text { mation systems for loading } \\
\text { and reloading devices with } \\
\text { the transition to full roboti- } \\
\text { zation and navigation }\end{array}$ & $\begin{array}{l}\text { Remote and operational } \\
\text { control and accounting of } \\
\text { operating and technical } \\
\text { parameters and synchro- } \\
\text { nized combined action } \\
\text { Dispatching, including } \\
\text { remote }\end{array}$ & $\begin{array}{l}\text { Increased expenses by } \\
10 \% \text { of the cost }\end{array}$ \\
\hline Functionality enhancement & $\begin{array}{l}\text { The use of conveyors with } \\
\text { suspended and folded } \\
\text { belts }\end{array}$ & $\begin{array}{l}\text { The use on complex and } \\
\text { changing transportation } \\
\text { routes Increase in a tilt an- } \\
\text { gle, size of the transported } \\
\text { cargo }\end{array}$ & Project individuality \\
\hline \multirow[t]{2}{*}{$\begin{array}{l}\text { Increase in (or operational } \\
\text { control over) productivity } \\
\text { with adaptation to fluctua- } \\
\text { tions in traffic }\end{array}$} & $\begin{array}{l}\text { Speed regulation and } \\
\text { asynchronous motor belt } \\
\text { drive control systems in } \\
\text { combination with loading } \\
\text { and reloading bins as a } \\
\text { function of cargo traffic }\end{array}$ & $\begin{array}{l}\text { Work in transport conveyor } \\
\text { lines, which are flexible in } \\
\text { terms of productivity }\end{array}$ & $\begin{array}{c}\text { High level of dispatching is } \\
\text { required }\end{array}$ \\
\hline & $\begin{array}{l}\text { Drive is in the form of mo- } \\
\text { tor-drum assemblies }\end{array}$ & $\begin{array}{l}\text { Reduced cost and dimen- } \\
\text { sions of the drive }\end{array}$ & Project individuality \\
\hline
\end{tabular}


velopment use, i.e., by the consumer of equipment, and the developer determines the amount of investments.

Also known is a principle, used in legal practice to determine the amount of losses from a decrease in the volume of production or sales of products, in the form of not received profits. It is defined as the difference between the price and the total planned cost per unit of products (works, services), multiplied by the number of products (works, services) not produced or not sold as a result of improper actions by the counterparty. Similar methods are used in the patent law in case of violation of the rights. In contrast to the meaning of terms "affected - accused," applied in legal practice, in this case, the enterprise can be considered as affected party if it does not use a technical solution for various reasons and bears, if not direct damage, then, substantially, loss of expected profits in the form of funds that could have been obtained. The amount of lost profits requires a complex economic analysis, since this refers to its hypothetical calculation, simulation of economic process under conditions of an expected, but never happened, event [25-26].

It is apparent that the profit margin of producing companies will vary significantly, so the actual amount of lost profits for business owners can be very different.

The absence of reliable data results to performing an expert comparative assessment of promising technical solutions (economic attractiveness of the project) in order of importance (as presented in the table) based on data on the increased performance, carrying capacity, lifespan and cost increase (costs for manufacturing additional equipment) and information on the payback period of the project.

\section{CONCLUSION}

The considered state of art in the field of transport engineering and trends in the enhancement of mining transport engineering with the criteria used in the study (including the level of logistics management, automation, productivity, labor costs for repair and maintenance, etc.) made it possible to determine current directions for further development of mining transport machines.

The research results reveal the investment attractiveness of using the considered technical solutions, improve the competitiveness and efficiency of the creation and use of transport machines and contribute to a significant modernization of transport systems of mining enterprises.

\section{REFERENCES}

1. Rasskazov, I.Y. \& Kryukov, V.G. (2018). Mining industry of the Khabarovsk Territory: Mineral resources and development prospects. Gornyi Zhurnal, 10, 5-12. https://doi.org/10.17580/gzh.2018.10.01
2. Tarasov, P.I., Zyryano, I.V. \& Khazin, M.L. (2018). New special-purpose transport for the Arctic. Mining Informational and Analytical Bulletin, 3, 136-147. https://doi.org/10.25018/0236-1493-2018-3-0-136147

3. Gromov, E.V., Bilin, A.L., Belogorodtsev, O.V. \& Nagovitsyn, G.O. (2018). Substantiation of Mining-and-Transportation System Type and Parameters for Mining of Ore Deposits in the Conditions of the on the Kola Peninsula. Journal of Mining Science, 54(4), 591-598. https://doi.org/10.1134/ S1062739118044051

4. Sedov, S. A., Valiev, I. N., Kuzmin, P. A., \& Sharifullina, A. M. (2014). On the issue of environment-oriented measures to eliminate the causes and reduce the effects of technogenic impact on the territory. Biosciences Biotechnology Research Asia, 11, 169-172. https://doi.org/10.13005/bbra/1456

5. Pimnev, A. L., Zemenkova, M. Y., Zemenkov, Y. D., \& Iljyashchenko, D. P. (2016). Mechanical properties of the assembly welded joint of the oil transportation tank after a long-term service. Paper presented at the IOP Conference Series: Materials Science and Engineering, , 127(1) https://doi.org/10.1088/1757899X/127/1/012049

6. Litvinenko, V. S., Sergeev, I. B. (2019). Innovations as a Factor in the Development of the Natural Resources Sector. Studies on Russian Economic Development, 30(6), 637-645. https://doi.org/10.1134/ S107570071906011X

7. Alenichev, V.M., Sytenkov, V.N., Kornilkov, S.V. \& Yakovlev, V.L. (2020). Open pit mining management strategy. Gornyi Zhurnal, 3, 34-39. https://doi. org/10.17580/gzh.2020.03.06

8. Galevskiy, G. V., Rudneva, V. V., Galevskiy, S. G., II'Yashchenko, D. P., \& Kartsev, D. S. (2016). Nanosized borides and carbides for electroplating. metal-matrix coatings: Specifications, performance evaluation. Paper presented at the IOP Conference Series: Materials Science and Engineering, , 125(1) https://doi.org/doi:10.1088/1757899X/125/1/012032

9. Rahman, P. A. (2017). Analysis of the mean time to data loss of nested disk arrays RAID-01 on basis of a specialized mathematical model. IOP Conference Series: Materials Science and Engineering, 177(1). https://doi.org/10.1088/1757-899X/177/1/012088

10. Koptev, V. Y. \& Kopteva, A.V. (2016). Mining business transportation system structure optimization. International Journal of Applied Engineering Research, 11(11), 7402-7405. 
11. Koptev, V. Y. (2017). Improving machine operation management efficiency via improving the vehicle park structure and using the production operation information database. IOP Conference Series: Materials Science and Engineering, 177(1). https://doi. org/10.1088/1757-899X/177/1/012005

12. Nekrasov, A.G. \& Sinitsyna, A.S. (2020). Digital transformation infrastructure and transportation logistics systems. IOP Conference Series: Materials Science and Engineering, 832(1). https://doi. org/10.1088/1757-899X/832/1/012052

13. Pinar Mizrak Ozfirat, Muharrem Kemal OOzfirat \& Tahir Malli. (2018). Selection of coal transportation mode from the open pit mine to the thermic power plant using fuzzy analytic hierarchy process. Transport, 33(2), 502-509 https://doi.org/doi:10.3846/164 84142.2017.1295278

14. Ghasemy Yaghin, R. \& Darvishi, F. (2020). Order allocation and procurement transport planning in apparel supply chain: A utility-based possibilistic-flexible programming approach. Fuzzy Sets and Systems, 398, 1-33. https://doi.org/10.1016/j.fss.2019.09.016

15. Zyryanov, I.V., Reshetnikov, S.V., Zolotukhin, G.K. \& Danilova, V.E. (2017). Enhancing hourly application efficiency of mining machinery at Mirny Mining and Processing Works, Alrosa. Gornyi Zhurnal, 3, 55-63. https://doi.org/10.17580/gzh.2017.03.10

16. Aleksandrov, V.I. \& Kibirev, V.I. (2018). The Kachkanarsky MCC iron ore processing tailings slurry hydraulic transport parameters determination. Obogashchenie Rud, 1, 56-63. https://doi.org/10.17580/ or.2018.01.10

17. Shishlyannikov, D.I. \& Lavrenko, S.A. (2016). Research of the mine shuttle car VS-30 drive mode. ARPN Journal of Engineering and Applied Sciences, 11(23), 13941-13944.

18. Kurganov, M.V., Gryaznov, M.V. \& Kolobanov, S.V. (2020). Assessment of operational reliability of quarry excavator-dump truck complexes. Journal of Mining Institute, 241, 10-21 https://doi.org/10.31897/ PMI.2020.1.1

19. Brailo, D.P., Gintner, S.N., Lunev, S.N. \& Andreeva L.I. (2016). Economics of repair works. Ugol' - Russian Coal Journal, 1, 45-46. https://doi. org/10.18796/0041-5790-2016-1-45-46
20. Andreeva, L.I. (2018). Machinery availability evaluation in mining. Mining Informational and Analytical Bulletin, 5, 136-143. https://doi.org/10.25018/02361493-2018-5-0-136-143

21. Asanov, A. \& Gumennikov, E. (2020). New Solutions for Mine Transport for the Transition to In-Line Mining of Minerals. Mining Science and Technology, 4, 262-272. https://doi.org/10.17073/2500-0632-20194-262-272

22. Safiullin, R.N., Afanasyev, A.S. \& Reznichenko, V.V. (2019). The concept of development of monitoring systems and management of intelligent technical complexes. Journal of Mining Institute, 237, 322-330. https://doi.org/10.31897/PMI.2019.3.322 S.322-330

23. Yemelyanov, V. A., Yemelyanova, N. Y., Nedelkin, A. A., Glebov, N. B., \& Tyapkin, D. A. (2019). Information system to determine the transported liquid iron weight. Paper presented at the Proceedings of the 2019 IEEE Conference of Russian Young Researchers in Electrical and Electronic Engineering, EIConRus 2019, 377-380. https://doi.org/10.1109/EIConRus.2019.8656693

24. Ponomarenko, T.V., Nevskaya, M.A. \& Marinina, O.A. (2018). Complex use of mineral resources as a factor of the competitiveness of mining companies under the conditions of the global economy. International Journal of Mechanical Engineering and Technology, 9, 1215-1223.

25. Afanasieva, N.V., Rodionov, D.G., \& Vasilev, Y.N. (2018). System of indicators of coal enterprise competitiveness assessment | Sistema de indicadores de evaluación de competitividad empresarial de empresas carboníferas. Espacios, 39(36).

26. Koptev, V.Y. \& Kopteva, A.V. (2017). Developing an Ecological Passport for an Open-Pit Dump Truck to Reduce Negative Effect on Environment. IOP Conference Series: Earth and Environmental Science, 66(1). https://doi.org/10.1088/1755$1315 / 66 / 1 / 012009$ 